Short segment Barrett's esophagus 沉発生した早期食道癌の 1 例

\author{
香川医科大学第 1 外科 \\ 出石邦彦石村健唐澤幸彦 \\ 合田文則臼杵尚志前田肇
}

\begin{abstract}
症例は44歳，男性．胸やけを主訴に近医受診.上部消化管内視鏡検查で下部食道の病 変を指摘され，当科紹介入院となった。食道透視では下部食道に長さ約 $1 \mathrm{~cm}$ ほどの壁の 硬化像および隆起性病変を認めた。内視鏡検查では下部食道に高さ約 $1 \mathrm{~cm}$ の鋸状の発 赤粘膜を認めた. その一部に径 $1 \mathrm{~cm}$ 弱の発赤した軽度の隆起性病変を認め, 同部の生検 により, 高分化腺癌と診断された。 以上より short segment Barrett's esophagus(SSBE) に発生した早期食道癌と診断し,非開胸にて下部食道および噴門側胃切除術を施行した. 切除標本では, 不正に入り込んだ最長的 $1 \mathrm{~cm}$ の発赤した食道粘膜を認め, 最長部に隆起 性病変を認めた。病理組織学的には, 食道下端にBarrett 上皮を認め, その一部で絬膜筋 板にまで達する大きさ $12 \times 7 \mathrm{~mm}$ のII a $+\mathrm{IIc}$ 型の高分化腺癌 (ly $1, \mathrm{v} 0, \mathrm{n} 0)$ を誌め た。退院後, 2 年後の現在まで再発は認めていない. SSBEに発生した食道癌は近年注目 を集めており，文献的考察を加え報告する。
\end{abstract}

真引用語：Barrett 食道, short segment Barrett's esophagus, 早期食道癌

\section{緒 言}

Barrett 食道は，逆流性食道炎を繰り返すことによ り，食道粘膜を形成する重層偏平上皮が障害され，下 部食道が胃粘膜から連続する円柱上皮で覆われた後天 性疾患である゙.一般的に円柱上皮が $3 \mathrm{~cm}$ 以上全周性 に伸展しているのを Barrett 食道と呼び, 食道腺㵧の 発生母地とされているが, $3 \mathrm{~cm}$ 末満のものは short segment Barrett's esophagus（SSBE）と呼ばれ, 同 样に煌化率が高いとする報告がある2).今回われわれ は,SSBEに発生した早期食道癌を経験したので, 若干 の文献的考察を加え報告する。

症例

患者：44歳, 男性.

主訴：胸やけ.

既往歴：特記すべきことなし.

家族歴：特記すべきことなし。

現病歴：2000年12月，胸やけを主訴に近医を受診し た際，上部消化管内視鏡検查で食道下端に約 $1 \mathrm{~cm} の$

2002年11月 5 日受付 2003 年 2 月 6 日採用 〈所属施設住所〉

テ761-0793 香川県木田郡三木町池戸1750-1
不整な発赤斑を認め, 生検で高分化腺癌が指摘された ため, 当院紹介受診となる.

入院時現症：身長 $169 \mathrm{~cm}$, 体重 $69 \mathrm{~kg}$. 理学的に貧血・ 黄㾝はなく，表在リンパ節も触知しなかった。胸腹部 にも異常所見は認めなかった。

血液検查所見：異常なし.

食道造影所見：下部食道右壁に長さ約 $1 \mathrm{~cm} の$ 壁の 硬化像抒よび隆起性病変（矢印）を認めた（図 1 ).

食道内視鏡所見：軽度の sliding hernia を認め,下 部食道の squamo-columnar junction 直上に全周性に 広がる高さ約 $1 \mathrm{~cm} の$, 血管模様の透見像が消失した 鋸状の発赤粘膜を認めた。その一部に径 $1 \mathrm{~cm}$ 弱の軽 度の陥凹を伴う隆起性病変 (矢印) を認め (図 2), 同 部の生㭘により, 高分化腺癌と診断された、下部食道 癌, II a + IIc, 樑達度 $\mathrm{m}$ と診断した。

超音波内視鏡所見：腫晹は（矢印）第 2 層にまで及 んでおり，深達度 $\mathrm{m}$ と診断した（図 3）。

手術: 平成 13 年 1 月 21 日, 上腹部正中切開 (非開胸) で下部食道および胃噴門側の切除術を施行するととも に, \#1，2，3の一部， 7，20のリンパ節郭清を行っ た. 再建は空腸間置術法を用いた. 術中, \#1, \#3のリ ンパ節および， 口側断端（約 $5 \mathrm{~mm}$ )を迅速病理に提出 


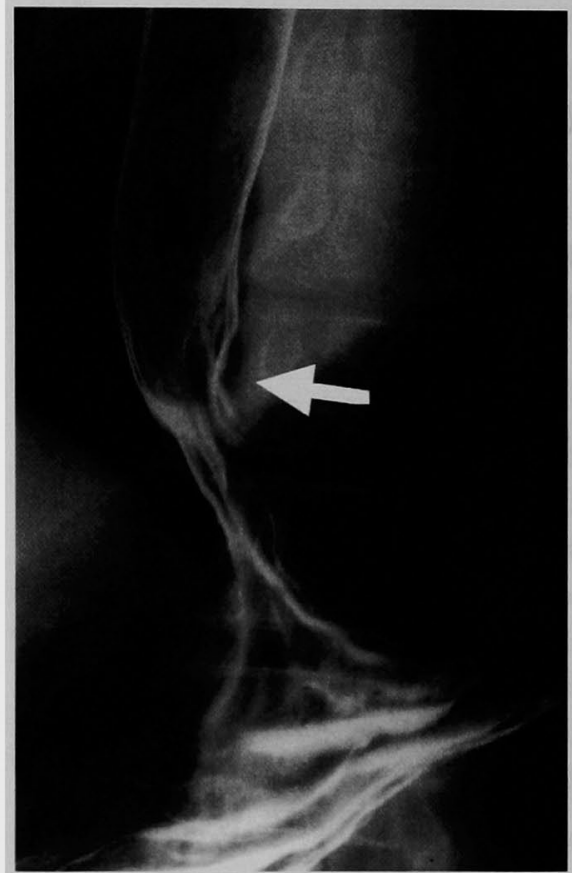

図 1 食道造影所見：下部食道右壁に長さ約 1 $\mathrm{cm}$ の隆起性病変（矢印）を認めた。

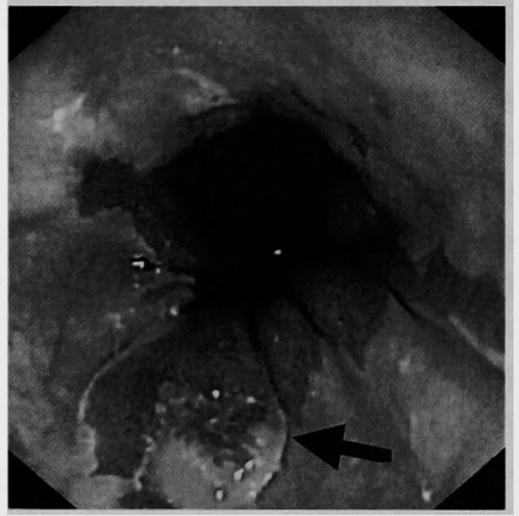

図 2 食道内視鏡所見：下部食道に高さ約 $1 \mathrm{~cm}$ の鋸状の発赤粘膜を認め, その一部 に陥凹を伴う隆起性病変 (矢印)を認めた。

したが，陰性であった。

切除標本肉眼所見 : 不正に入り組んた最長約 $1 \mathrm{~cm}$ の発赤した鋸状の食道粘膜を認め, 最長部に中心樎凹 を伴う隆起性病変（矢印）を認めた（図 4).

病理組織学的：下部食道に管腔構造を示しながら粘 膜筋板にまで達する粘膜内癌が広がっており，全体の

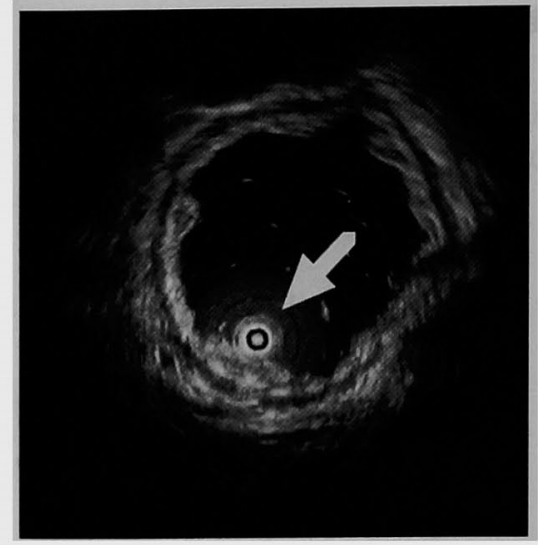

図 3 超音波内視鏡所見：腫瘍は（矢印）第 2 層にまで及でいた.

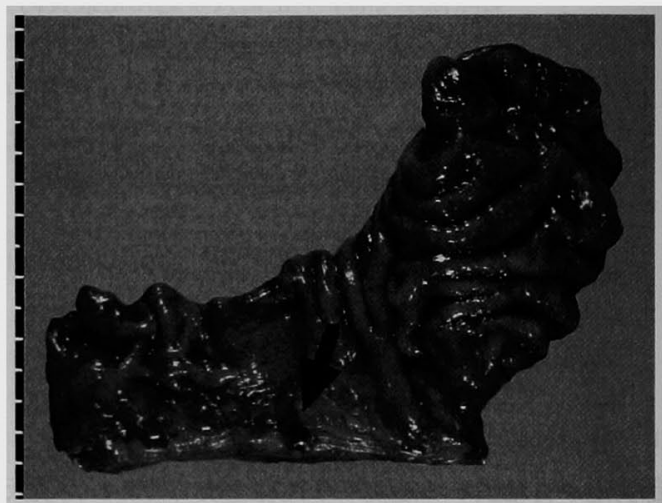

図 4 切除標本 : 不正に入り組んだ最長約 $1 \mathrm{~cm}$ の発赤 した鈮状の食道粘膜を㒛め，最長部に中心陥凹を伴う 隆起性病変を認めた. 口側断端は $0.5 \mathrm{~mm}$ であった。

病変の大きさは $12 \times 7 \mathrm{~mm}$ であった（図 5 )。病変の粘 膜下層には食道固有腺を認め, 島状の偏平上皮の遺残 を認めたため SSBEに発生した早期食道腺癌と診断 した．組織診断は II a + IIc 型の高分化腺癌 (tub l), $\mathrm{m}$, ly 1 , v0, no (\#1:0/2, \#2:0/4, \#3:0/ 3 ,\#7:0/0,\#20:0/0),pPM(-):0.5mm, pDM (一):20mm, pEM：6 mmであった。なお, 標本上, 口側断端は, $0.5 \mathrm{~mm}$ と診断されたが, 迅速病理提出分 の $5 \mathrm{~mm}$ に加え, 自動吻合器による吻合時に切除した 部分（病理学的には negative）を考え，最終的には粘 膜癌の断端として十分であると判断した。

術後経過は順調で, 術後24日で退院となった。現在, 外来で経過観察を行っているが, 術後 2 年まで再発は 認めていない。 


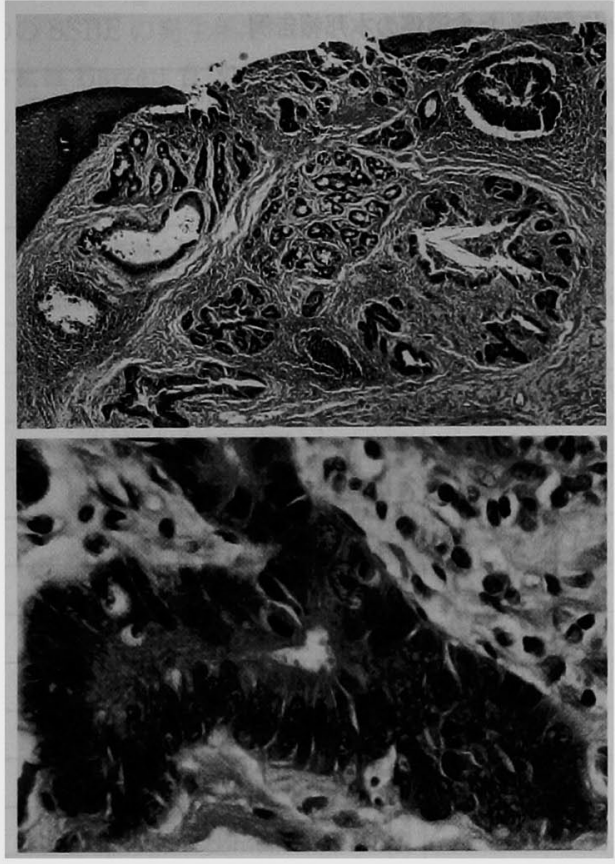

図 5 病理組織学的：下部食道に高分化腺癌が粘膜 筋板にまで広がっていた，病変部には食道固有腺 と島状の偏平上皮の遺残を認めた（A：H\&E, X 40, B : H\&E, $\times 400)$.

\section{考 察}

Barrett 食道は食道胃接合部より $3 \mathrm{~cm}$ 以上, 全周性 に円柱上皮が食道側に進展しているものをさすのに対 し3，SSBEは，この定義を満たさないより短い Barrett 粘膜 $(3 \mathrm{~cm}$ 末満のもの）とされる4). SSBEは Barrett 食道の形成過程の一部として捉えられてい る.すなわち逆流性食道炎により障害された食道扁平 上皮が円柱上皮で置換され，その円柱上皮部分の長さ が短いSSBEから Barrett 食道が形成されると考え られている.この進展過程の詳細は明らかでないが, 河野ら ()は，経過観察症例の検討において，大部分の SSBE は進展せず，一部のものだけが少しずつ一定で はなく，ある時期に急速に進展をしめしたと報告して いる.

SSBE の特徵として, Weston ら`は，74例の SSBE と78例の Barrett 食道とを対比検討し，SSBE は黒人 に, Barrett 食道は白人に多く，このうち dysplasia は SSBE の8.1\%, Barrett 食道の $24.4 \%$ に認められたと している.黄色人種でも黒人同様に SSBEが多いとさ れる6), 本邦では, 同一検者の集団健康診断群や定期健
康診断群では Barrett 食道発生率は0.3\%, SSBE の発 生率は約 $6 \%$ と報告されている778). Barrett 食道の癌 化率については, 欧米では2.4〜 46\%と様々な報告があ $\eta^{9) 10)}$, prospective studyでは2.4\%と報告されてい る11)12). SSBE の癌化率については, Barrett 食道に比 べ，癌化率は低いと思われるものの，大規模な SSBE の癌化率に対する prospective study は行われておら ず，その癌化率については不明である.

本邦において，SSBEに発生した癌の報告例を医学 中央雑誌ならびに消化器関連雑誌で検索したところ, 自験例を含め，32例（表 1）が報告されていた。この 内, $94 \%$ (30/32) が男性で, 年齢は $44 か ら 90$ 歳であっ た. 28例に対して外科的切除が施行され，4例に対し て内視鏡的切除が施行されていた。深達度は $\mathrm{m}$ 癌が 41 $\%(13 / 32), \operatorname{sm}$ 癌が34\%(11/32), mp 以深が25\%(8/ 32）であった。また，リンパ節転移は全体で $31 \%$ (8/ 26)に認め, 深達度ごとの転移頻度は, $m$ 癌, sm 癌で は $0 \%$ (それぞれ $0 / 9 ， 0 / 9)$ ，mp 以深では $100 \%$

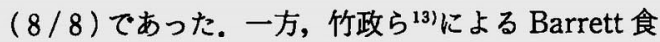
道癌83例の集計では，76\% (63/83) が男性，年齢は19 から95歳, 深達度は $\mathrm{m}$ 癌17\%(11/64), sm 癌38\%(24/ 64), mp 以深45\% (29/64) であり，46\% (26/57) に リンパ節転移を認めたと報告している。これらを比較 すると，SSBEに発生した食道癌の方がやや男性に多 く，より早期の癌が多いことが特徴であった。

治療法に関して言えば，竹政らは， $\mathrm{m}$ 癌を含めた表 在癌としては，外科的切除が第一であるとしており， われわれの集計でも外科的切除が多く行われていた. $\mathrm{m}$ 癌の13例中10例に手術が行われ，3例に内視鏡的粘 膜切除が施行されていた。このうち記載のある 9 例の 手術症例についてはリンパ節転移を認めていない. SSBEであれば必ず $\mathrm{m}$ 癌といったわけでなく, sm 癌 の可能性を考えると外科的切除が必要であると考える が, EUSなどにより深達度診断が正確に行われ $\mathrm{m}$ 癌 と診断されれば, 内視鏡的粘膜切除, あるいは photodynamic therapy (PDT) も治療の選択肢として あげられ"，今後の予後に対する検討が待たれる。

\section{結語}

日本人の生活様式の変化と, H. pylori の感染率の低 下により，本邦でも逆流性食道炎や Barrett 食道が増 加し ${ }^{1) 4}$ ，ひいてはSSBE も増加すると思われる. Barrett 食道癌手術症例の五年生存率は, $\mathrm{m}$ - sm 癌では95 \%以上と非常に良好であるのに対し， mp 以深では 25 \%以下と極端な差がある ${ }^{14)}$. SSBE の癌化率は低いも 
表 1 Short segment Barrett's esophagusに発生した食道澏の本邦報告例

\begin{tabular}{|c|c|c|c|c|c|c|c|c|c|c|c|c|c|}
\hline No & Reporter & Year & Age & Sex & Type & Histlogy & Depth & $\begin{array}{l}\text { Tumor } \\
\text { size } \\
(\mathrm{cm})\end{array}$ & \begin{tabular}{|l|} 
Length of \\
Barrett's \\
esophagus \\
(cm)
\end{tabular} & ly & $\mathrm{v}$ & $\mathbf{n}$ & Treatment \\
\hline 1 & 音琴 & 1989 & 72 & $\mathrm{~F}$ & $0-\mathrm{II} a+\mathrm{II} c$ & tubl & $\mathrm{m}$ & $7.0 \times 2.0$ & $<3$ & - & - & - & 右開胸食道监全摘術 \\
\hline 2 & 今田 & 1989 & 84 & M & $0-\mathrm{II} a$ & well & sm & $1.5 \times 1.5$ & $<3$ & * & - & - & 左開胸下部食道噴門側切除術 \\
\hline 3 & 西 & 1995 & 50 & M & IIc & tubl & $\mathrm{m}$ & 0.8 & 1.5 & - & - & - & 下部食道磺門部切除術 \\
\hline 4 & 小沼 & 1995 & 77 & $\mathrm{M}$ & $0-\mathrm{IIa}$ & tubl & $\mathrm{sm}$ & 0.7 & $<3$ & - & $\cdot$ & - & EMR後, 食道噴門切除街 \\
\hline 5 & 中村 & 1997 & 66 & $\mathrm{M}$ & 2 & por & $\mathrm{a} 2$ & . & 2.3 & * & $*$ & + & 右開胸下部食道切除術 \\
\hline 6 & & & 68 & $\mathbf{M}$ & 3 & por & a2 & - & 2.8 & * &. & + & 左開胸下部食道切除術 \\
\hline 7 & & & 59 & $\mathbf{M}$ & 3 & $\bmod$ & a2 & * & 1.8 & * & $*$ & + & 右開胸食道带全摘術 \\
\hline 8 & & & 59 & F & 3 & por & al & - & 2.3 & . & $\cdot$ & + & 左開胸食道垔全摘術 \\
\hline 9 & & & 46 & M & $0-I p$ & well & $\mathrm{sm}$ & . & 1.4 & * & $*$ & - & 右開胸食道垔全摘術 \\
\hline 10 & & & 60 & M & $0-$ III & $\bmod$ & al & - & 2.3 & (* & * & + & 右開胸食道型全摘術 \\
\hline 11 & & & 48 & M & $0-I p$ & pap & $\mathrm{mm}$ & - & 2.4 & . & $\cdot$ & - & 非開胸食道抜去術 \\
\hline 12 & & & 90 & $\mathrm{M}$ & $0-I \mathrm{pl}$ & por & $\mathrm{sm}$ & . & 2.2 & $*$ & $*$ & - & 非開胸食道抜去術 \\
\hline 13 & & & 66 & M & $0-\mathrm{I} \mathrm{pl}$ & $\bmod$ & $\mathrm{sm}$ & - & 1.8 & . & * & - & 左開胸下部食道切除術 \\
\hline 14 & & & 60 & M & 3 & muc & $\mathrm{mp}$ & - & 2.2 & $*$ & $\cdot$ & + & 左開胸食道垔全摘術 \\
\hline 15 & 小倉 & 1999 & 59 & M & $0-$ II c & well & $\mathrm{m}$ & 1.0 & $<2$ & $*$ & $*$ & - & 左開胸下部食道噴門側胃切除術 \\
\hline 16 & 塩見 & 1999 & 78 & M & 1 & well & al & 3.0 & $<3$ & + & + & + & 腹部食道，胃全摘術 \\
\hline 17 & 鈴木 & 1999 & 66 & $\mathbf{M}$ & $0-\mathrm{II} c$ & tub2 & $\mathrm{m}$ & $2.4 \times 1.0$ & 1.5 & + & + & * & 右開胸胸部中下部食道切除術 \\
\hline 18 & 吉村 & 1999 & 60 & $\mathbf{M}$ & $0-$ II c & tubl & sm & - & 2 & $*$ & * & * & operation \\
\hline 19 & 藤濢 & 1999 & 65 & M & $0-1$ sep & tub2 & $\mathrm{sm}$ & $1.7 \times 1.6$ & 0.7 & - & - & - & 右開胸下部食道整門側胃切除衞 \\
\hline 20 & 大芝 & 1999 & 56 & $\mathbf{M}$ & $0-I$ & tubl & $\mathrm{sm}$ & $2.2 \times 1.2$ & 2.5 & - & - & - & 右開胸下部食道噴門側胃切除術 \\
\hline 21 & 門馬 & 1999 & 78 & M & $0-11 \mathrm{c}$ & tubl & $\mathrm{m}$ & $1.5 \times 5.5$ & 1.5 & - & - & - & 下部食道切除術，残胃全摘術 \\
\hline 22 & 星原 & 1999 & 73 & M & $0-I I c$ & tubl & $\mathrm{sm}$ & 1.0 & $<3$ & - & $*$ & * & EMR \\
\hline 23 & 畐松 & 1999 & 51 & $\mathbf{M}$ & $0-1+\mathrm{II} a+\mathrm{IIb}$ & tub1 & $\mathrm{sm}$ & $3.0 \times 2.8$ & 1.8 & + & - & - & operation \\
\hline 24 & & & 63 & M & $0-\mathrm{II} \mathrm{c}$ & tubl & $\mathrm{mp}$ & $2.1 \times 1.5$ & 1 & - & + & + & operation \\
\hline 25 & & & 51 & M & $0-$ II & tubl & $\mathbf{m}$ & $1.7 \times 0.7$ & 2.2 & - & - & - & operation \\
\hline 26 & & & 59 & M & $0-$ II c & tubl & $\mathrm{m}$ & $1.0 \times 0.8$ & 1.3 & - & - & - & operation \\
\hline 27 & 大下 & 2000 & 78 & $\mathbf{M}$ & $0-$ II a & tubl & $\mathrm{m}$ & 0.3 & 1 & * & 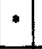 & $*$ & EMR \\
\hline 28 & 新海 & 2000 & 70 & $\mathbf{M}$ & $0-11 \mathrm{c}$ & $\bmod$ & $\mathrm{m}$ & 1.0 & $<3$ & - & - & - & 部分切除 \\
\hline 29 & 池田 & 2000 & 63 & $M$ & $0-\mathrm{II} a$ & tubl & $\mathrm{sm}$ & 2.0 & 2 & + & + & - & 右開胸下部食道噴門側罢切除術 \\
\hline 30 & 縜藤 & 2002 & 45 & M & $0-11 \mathrm{a}$ & tubl & $\mathrm{m}$ & 1.5 & 2.5 & - & - & * & EMR \\
\hline 31 & 山根 & 2002 & 57 & $\mathrm{M}$ & $0-$ II c & tub1 & $\mathrm{m}$ & $1.2 \times 0.8$ & 1.5 & - & - & * & EMR \\
\hline 32 & 自験例 & 2003 & 44 & $M$ & $0-\mathrm{II} a+\mathrm{II} c$ & tubl & $\mathrm{m}$ & $1.2 \times 0.7$ & 1.0 & + & - & - & 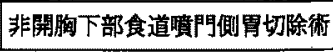 \\
\hline
\end{tabular}

* : not descrived, - : negative, + : positive, EMR : Endoscopic mucosal resection. 
のの SSBE の発生頻度は高く，食道癌を早期に発見す るには Barrett 食道ばかりではな, SSBE に対して も十分に注意を払うことが重要であると思われる。

\section{文献}

1）幕内博康：Barrett 食道の診断と治㙩。消内視镜 $9: 879-889,1997$

2) Skinner DB, Walther BC, Little AG: Surgical treatment of Barrett's esophagus. In Spechler SJ, Goyal RK (eds), Barrett's Esophagus, Pathophysiology, Diagnosis, and Management, Elsevier Sci Publ Co, New York, 1985, p211-221

3) Wijnhoven BP, Tilanus HW, Dinjens WN: Molecular biology of Barrett's adenocarcinoma. Ann Surg 233: 322-337, 2001

4）河野辰幸, 中村正徳, 川田研郎他：Short-segment Barrett 食道. 内科 $87: 1098-1102,2001$

5) Weston AP, Krmpotich PT, Cherian R, et al: Prospective long-term endoscopic and histological follow-up of short segment Barrett's esophagus : comparison with traditional long segment Barrett's esophagus. Am J Gastroenterol $92: 407-413,1997$

6）大芝 玄, 幕内博康, 島田英雄他：short segment Barrett's esophagus から発生し, 異形成を伴う早 期 Barrett 食道癌の 1 例. 胃と腸 $34: 189-194$, 1999
7）熊谷義也, 陶山匡一郎, 向井万起男他: Barrett 上 皮の頻度と成因について (第 1 報)，消内視鏡の進 歩 $27: 80-83,1985$

8）西 隆之, 幕内博康, 水谷郷一他：内視鏡スクリ 一ニングで発見された Barrett 食道・Barrett 上 皮について.クリニカ 23:14-19, 1996

9) Hawe A, Payne WS, Weiland LH, et al: Adenocarcinoma in the columnar epithelial lined lower (Barrett) oesophagus. Thorax 28 : 511-514, 1973

10) Skinner DB, Walther BC, Riddell RH, et al : Barrett's esophagus. Comparison of benign and malignant cases. Ann Surg 198:554-565, 1983

11) Bremner CG : Barrett's esophagus. Br J Surg $76: 995-996,1989$

12) Bernstein IT, Kruse P, Andersen IB : Barrett's esophagus. Dig Dis 12 : 98-105, 1994

13）竹政伊知朗, 小林研二, 福田和弘他：Barrett 食道 から発生した食道表在腺癌の 1 例. わが国の報告 Barrett 食道癌83例，及び表在癌35例の検討。癌の 臨 $43: 262-266,1997$

14) Riddell RH : Early detection of neoplasia of the esophagus and gastroesophageal junction. Am J Gastroenterol 91 : 853-963, 1996

\title{
EARLY ADENOCARCINOMA IN SHORT SEGMENT BARRETT'S ESOPHAGUS -REPORT OF A CASE-
}

\author{
Kunihiko IZUISHI, Ken ISHIMURA, Yukihiko KARASAWA, \\ Fuminori GODA, Hisashi USUKI and Hajime MAETA \\ First Department of Surgery, Kagawa Medical University
}

A 44-year-old man complaining of heartburn was referred to the hospital for close exploration of an esophageal elevated lesion found at another hospital. Barium esophagograms revealed a slightly elevated lesion with surrounding mucosal irregularity of the lower thoracic esophagus. Endoscopic examination revealed reddish and rough mucosa with maple-leaf-like shape on the oral side of squamo-columnar junction, and an elevated lesion with a central depressed component. Biopsy specimens sampled from the main lesion was diagnosed as well differentiated adenocarcinoma and this case was diagnosed as adenocarcinoma arising from the short segment Barrett's esophagus. Distal esophagectomy and a proximal gastrectomy without thoracotomy was performed. Histological examination of the resected specimen showed Barrett's epithelium in the lower esophagus, and well-differentiated adenocarcinoma limited in mucosa (IIa $+\mathrm{IIc}, \mathrm{m}, \mathrm{ly} 1, \mathrm{v} 0, \mathrm{n} 0,12 \times 7 \mathrm{~mm}$ ) in it. Postoperative course was uneventful, and no recurrence has been observed over 2 years. The case of adenocarcinoma arising from the short segment Barrett's esophagus, which has recently attracted clinical attentions is reported together with a review of the Japanese literature. 